\title{
EVALUATION OF THE PERFORMANCE OF THE DOMESTIC WASTEWATER TREATMENT FACILITY OF A HOTEL IN PORT HARCOURT, RIVERS STATE NIGERIA
}

\author{
A. W. Otunyo ${ }^{1,}{ }^{*}$, K. Edward ${ }^{2}$ and O. D. Ogina ${ }^{3}$ \\ 1,2 3 Dept of Civil Engr. Rivers State Univ. of Science \& TeCh. NKPolu Port Harcourt, Rivers State. NiGERIA. \\ E-mail addresses:1 umutuigili@yahoo.com,2letamkue@yahoo.com,3desmondnike@yahoo.com
}

\begin{abstract}
The efficiency of the biological treatment of domestic wastewater produced in a hotel in Port Harcourt, Rivers State, Nigeria sitting on a clay laden soil, was evaluated in this study. The biological treatment process involved is an activated sludge system. Wastewater from the hotel's septic tank and treated water from the discharge from the activated sludge treatment plant was collected and analysis carried out in the laboratory to determine the extent of COD, BOD, TSS, $\mathrm{NH}_{3}$, Sulphate, TDS and Salinity in the wastewater as well as the treated water. The COD, BOD and TSS dropped from $45 \mathrm{mg} / 1,20.05 \mathrm{mg} / \mathrm{l}$ and $35 \mathrm{mg} / \mathrm{l}$ respectively to $20 \mathrm{mg} / \mathrm{l}, 7 \mathrm{mg} / \mathrm{l}$ and $10 \mathrm{mg} / \mathrm{l}$. While the $\mathrm{NH}_{3}$, Sulphate, TDS and Salinity dropped from $27.65 \mathrm{mg} / 1,450.08 \mathrm{mg} / 1,1800 \mathrm{mg} / \mathrm{l}$ and $508.06 \mathrm{mg} / \mathrm{l}$ respectively to $11.55 \mathrm{mg} / \mathrm{l}, 300 \mathrm{mg} / \mathrm{l}, 1000 \mathrm{mg} / \mathrm{l}$ and $450 \mathrm{mg} / \mathrm{l}$. The domestic wastewater treatment plant of $500 \mathrm{~m}^{3} /$ day capacity had an efficient treatment capability. All parameters, except, lead and chromium met DPR standard. However chromium met the FMENV Standard. The outlet wastewater after the treatment process also met the Federal Ministry of Environment Standard. The significance of the study is that the activated sludge wastewater treatment plant could be economically deployed in areas where there is availability of electricity and semi-skilled manpower..
\end{abstract}

Keywords: Wastewater, biological treatment, activated sludge.

\section{INTRODUCTION}

Water is a clear, colourless, odourless and tasteless liquid substance essential for most plant and animal life and a mostly used solvent [1]. Increased water use and process wastewater generation requires more efficient removal of by-products and pollutants that allow for effluent discharge within established environmental limits. Biological treatment is an important and integral part of any wastewater treatment plant that treats wastewater from either municipality or industry having soluble organic impurities or a mix of the two types of wastewater sources [2]. Wastes that can contaminate sources of water supply and cause health problems include human and animal faeces, solid wastes, domestic waste water, industrial waste and agricultural waste [3]. Studies in [4], reported the fact that wastes disposal (including septic sludge) has been identified as one of the principal factors responsible for the flooding of Ogunpa stream in Nigeria.
Biological treatment of wastewater is less expensive than other treatment processes like chemical oxidation, thermal oxidation etc. This is in both terms of capital investment and operating costs, The use of microorganisms to remove contaminants from wastewater is effective and widespread, this in a nutshell is what is referred to as Biological treatment. Most buildings in rural areas and sited on pervious soil deploy the septic tank with gravity draining of the wastewater into the soil coupled with periodic evacuation of the solid sludge. The waste water draining into the soil is untreated. The activated sludge system ensures that the outlet water from the septic tank after passing through the activated sludge process is treated before injection into the surrounding municipal drain or into any water body or land mass. The solid sludge is then later evacuated. The term "septic" refers to anaerobic bacterial environment that develops in the tank which decomposes or mineralizes the waste discharged into

* Corresponding author Tel: +234- 803-310-6918 
the tank. Septic tank can be coupled with other onsite wastewater treatment units such as biofilters or aerobic systems involving artificially forced aeration [5].

The report in [6] stated that when considering biological wastewater treatment for a particular application, it is important to understand the sources of the wastewater generated, typical wastewater composition, discharge requirements, events and practices within a facility of the wastewater, and pretreatment ramifications.

Consideration of these factors will allow one to maximize the benefits of the plant gains from effective biological treatment. Those benefits include

- Low capital and operating costs compared to those of chemical-oxidation.

- True destruction of organics, versus mere phase separation, such as with air stripping or carbon adsorption.

- Oxidation of a wide variety of organic compounds.

- Removal of reduced inorganic compounds, such as sulfides and ammonia, and total nitrogen removal possibility through denitrification.

- Operational flexibility to handle a wide range of flow and wastewater characteristic.

- Reduction of aquatic toxicity [6].

In order to allow for a proper understanding of the discussion, it is important to clearly define certain important terms- viz, aerobic and anaerobic.

Aerobic suggests in the presence of air (oxygen) while anerobic means in the absence of air (oxygen). The types of bacteria or microorganisms that are involved in the degradation of organic impurities in a given wastewater and the operating conditions of the bioreactor directly relate to aerobic and anerobic conditions.

Aerobic treatment processes takes place in the presence of air and utilize those microorganisms (also called aerobes), which use molecular/free oxygen to assimilate organic impurities, that is, convert them into carbon dioxide, water and biomass. The anaerobic treatment processes, on the other hand take place in the presence of microrganisms (also called anaerobes) which do not require air (molecular/free oxygen) to assimilate organic impurities [2]. For phosphorous removal, biological processes are configured to encourage the growth of bacteria with the ability to take up and store large amounts of inorganic phosphorous. Phosphorous removal in biological system is based on the following observations [7].
- Numerous bacteria are capable of storing excess amount of phosphorous as polyphosphates in their cells.

Under anaerobic conditions, PADS will assimilate fermentation products (e.g. volatile fatty acids) into storage products within the cells with concomitant release of phosphorous from stored polyphosphates.

- Under aerobic conditions, energy is produced by the oxidation of storage products and polyphosphates as the cells increase.

In Nigeria, the major liquid wastes comprise sullage or grey water and industrial effluents. As the human excreta are separately managed through a large number of practices, the wastewater is supposed to be devoid of it. The only exception being when people defecate indiscriminately into drains. Sullage is domestic wastewater other than that which comes from the toilet. It is also called grey water (to distinguish it from black-water which describes wastes containing human excreta). Grey water is used in urban agriculture, therefore they are a priced resource.

The report in [8]concluded that Public Health has been threatened due to exposure of the residents and unprotected waste handlers to untreated sludge in Ibadan metropolis arising from septic tanks and pit toilets.

Wastewater in most residential and industrial areas in Port Harcourt are not treated. Septic tanks draining directly into the ground and therefore leading to seepage of contaminated water into the ground and evacuation of solid wastes is the common practice. The term "septic" refers to anaerobic bacterial environment that develops in the tank which decomposes or mineralizes the waste discharged into the tank.

The activated sludge system ensures that the outlet water from the septic tank after passing through the activated sludge process is treated before injection into the surrounding municipal drain or into any water body. The solid sludge is then later evacuated.

There are advantages and disadvantages inherent in the use of the activated sludge process for waste water treatment.

A major advantage is the fact that the treated water in the activated sludge treatment process is that the effluents discharge meets the regulatory standards, therefore the concern about pollution of the environment is eliminated when the treated water is discharged to other water body or nearby land locations. 
The disadvantages of the process include the following: (i) requirement for electricity and (ii) trained manpower, (iii) availability of chemicals used in the treatment process.

A hotel located in Port Harcourt, Rivers State Nigeria, is sited on a soil having a massive layer of clay underneath the surface. As a result septic tanks cannot be effective and economical.

An activated sludge treatment process was installed for the biological treatment of the black-water produced in the hotel. The effluent from the activated sludge treatment process of the hotel, having satisfied the WHO and FEMNV Standards is piped to the closed drain in the vicinity which eventually empties into the INTER-NWOGBA Creek in Diobu Area of Port Harcourt.

This case study evaluated the efficiency of the biological treatment for domestic wastewater (blackwater) produced in the hotel, using the activated sludge treatment process.

\section{METHOD}

Fig. 1 shows the block diagram representing the flow process of the method used for the wastewater treatment plant of a hotel in Port Harcourt. A brief description of the process diagram of Fig 1 is as follows.

(a) Raw wastewater (black-water) from the hotel sanitary system flows through a sewer pipe into a chamber. The chamber serves as an inspection unit to check materials, especially inorganic substances that flow in, since these materials could oppose free flow of the wastewater for further treatment.

(b) From the chamber, the wastewater flows into the septic tank. In the septic tank, the solid matter in the influent settles and are disintegrated with the aid of bacteria.

(c) Effluent from the septic tank rich in nutrient with microbial suspension flows into the aeration tank.

(d) The effluent wastewater with microbial mass is referred to as mixed liquour suspended solids (MLSS). The dominant organisms are bacteria of which there are different species present. Oxygen is bubbled into the aeration tank with a compressor to enable metabolism of bacteria. Metabolism comprises thousands of simultaneous chemical reactions that are occurring at any time inside the bacteria.

(e) The MLSS from the aeration tank is pumped into the reactor vessels. These vessels contain screens.
Further settlement of solids is achieved here. The oxygen level in the MLSS is low, therefore respiration will be inhibited and hence energy will not be available for bacteria growth. As a result, the micro-organisms that settle in the MLSS, stay without food (due to low DO (dissolved oxygen). They become hungry thus they are activated. This is the origin of the term "Äctivated Sludge System".

(f) A fixed mass of the microorganism are pumped back to the aeration tanks, where they find food i.e. organisms in the effluent from the septic tank. The process is repeated hence the activated sludge system is a continuous process. Further settlement of flock particles takes place in the reactor vessel. These particles are removed by gravity settling, leaving a relatively clear liquid at the treated effluent.

(g) The treated effluent flows into a chlorine well where the excess settled particles are shoveled out. The chlorine well is a concrete box where post chlorination is done (administration of chlorine at the end of the treatment process). This is achieved by introducing chlorine tablets upon depletion of the chlorine tablets in the chlorine well.

(h) Finally, the treated effluent flows into the municipal closed drain which empties into the INTER-NWOGBA Creek in the Diobu Area of Port Harcourt.

The following safety precautions were taken during the collection and analysis of the waste water samples: (i) hands were washed frequently with antibacterial soap and warm water, (ii) hand sanitizers were used when soap and water were not readily available, (ii) eating or drinking or smoking in work areas was not allowed (iv)avoidance of touching of eyes, nose, face or mouth unless hands have been recently washed, (v) flushing of eyes, nose or mouth with potable water immediately a splash of wastewater occurred, (vi) work clothes, gloves and boots were not allowed into homes (vii)disposable gloves were worn during execution of all the tasks, (viii) hands were not allowed to be submerged below top of gloves (ix) soiled clothes were changed immediately (x) it was not permitted to pick up sharp items or broken glass without protecting hands by wearing leather gloves. (xi) nose masks, googles or face shields were worn during prolonged expose to waste water, (xii) disposable latex or synthetic gloves was worn at all times when it was anticipated that 
hands will come in direct contact with sewage, (xiii) all scraps, cuts and burns were covered before contact with sewage.

\subsection{Determination of treatment efficiency}

In order to determine the treatment efficiency of the system, treated and untreated wastewater samples were collected and analyzed in ROFNEL ENERGY SERVICES LTD. Plot 2 Adison Close Rumuagholu, Port Harcourt. Raw wastewater samples were from the septic tank using a suction pump inserted through the breathing hole of the septic tank, with a sterile $500 \mathrm{ml}$ bottle and 2 (125) polystyrene containers. The treated water samples were collected from the point of exit from the treatment plant. Sample collection bottles were rinsed twice before filling and they were subsequently corked tight and immediately taken to the laboratory where they were stored in a refrigerator to avoid further chemical reaction..

Table 1 shows the parameter analytical method employed, method detection limit and equipment type used Table

\begin{tabular}{lllll}
\hline S/N & \multicolumn{1}{c}{ PARAMETERS } & \multicolumn{1}{c}{ Method } & Detection Limit & Equipment \\
\hline 1 & PH & ALPHA 4500-H[9] & 1 & HANNAH Multi Para-meter Meter \\
2 & Total Dissolved Solids(TDS) & ALPHA 2520B & 1 & HANNAH Multi Para-meter Meter \\
3 & Conductivity & ALPHA 2510-B & 1 & HANNAH Multi Para-meter Meter \\
4 & Turbidity & ASTM D1889 [10] & 0.01 & HACH UV Spectrophotometer \\
5 & Total Suspended Solids (TSS) & ALPHA 2540-D & 0.00 & HACH UV Spectrophotometer \\
6 & Dissolved Oxygen (DO) & ALPHA 4500-H & 0.01 & HANNAH Multi Para-meter Meter \\
7 & Chemical Oxygen Demand (COD) & ASTM D1125 & 0.01 & HACH COD Reactor \\
8 & Biological Oxygen Demand (BOD) & ASTM D1125 & 0.01 & Aerobic Incubator \\
9 & Salinity (as Chloride) & APHA 4500 & 0.01 & HANNAH Multi Para-meter Meter \\
10 & Nitrate & APHA 4500 & 0.01 & HACH UV Spectrophotometer \\
11 & Nitrite & APHA 4500 & 0.01 & HACH UV Spectrophotometer \\
12 & Sulphate & ASTM D516 & 1.00 & HACH UV Spectrophotometer \\
13 & Phosphate & ASTM D515 & 0.01 & HACH UV Spectrophotometer \\
14 & Lead,(Pb) & APHA 311B & 0.04 & Atomic Absorption Spectrophotometer \\
15 & Zinc (Zn) & APHA 311B & 0.005 & Atomic Absorption Spectrophotometer \\
16 & Chromium, (Cr) & APHA 311B & 0.04 & Atomic Absorption Spectrophotometer \\
\hline
\end{tabular}

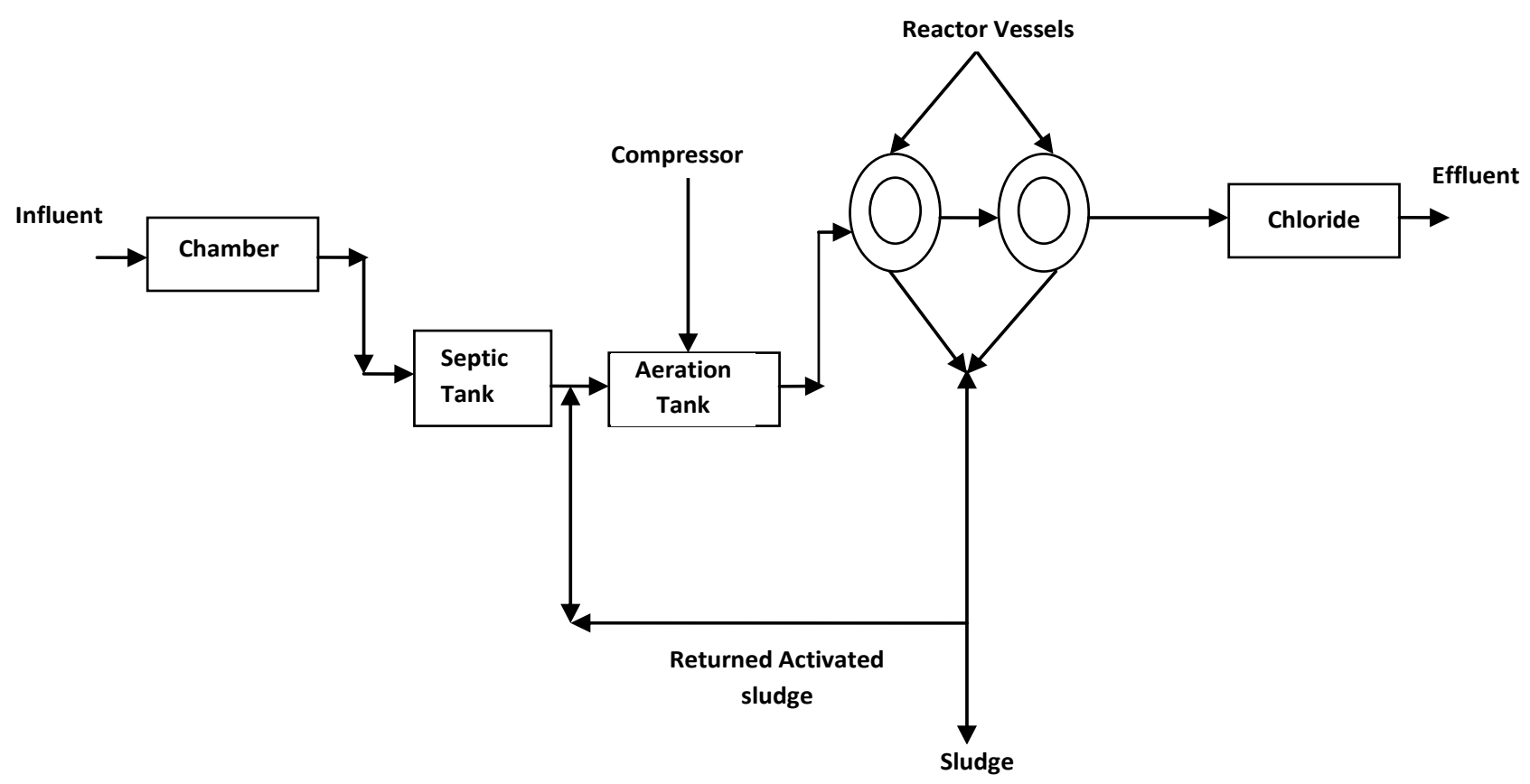

Fig. 1: Block Diagram representing the flow process of the wastewater treatment plant in Amanda Hotels Itd. Port Harcourt. 


\subsection{Regulatory standard for discharge of effluents (FMENV)}

The regulatory standard according to the FEMNV are as stated below.

COD $\leq 40 \mathrm{mg} / \mathrm{l}$,

BOD $\leq 10 \mathrm{mg} / \mathrm{l}$

TSS $\leq 30 \mathrm{mg} / \mathrm{l}$

$\mathrm{NH} 3 \leq 20 \mathrm{mg} / \mathrm{l}$

Sulphate $\leq 500 \mathrm{mg} / \mathrm{l}$

TSS $\leq 2000 \mathrm{mg} / \mathrm{l}$

Salinity $\leq 600 \mathrm{mg} / \mathrm{l}$

\section{RESULT AND DISCUSSIONS}

Figures 2-8 in sections $3.1-3.7$ shows in graphical form the percentages of the various parameters tested at entry and outlet of the activated sludge treatment plant as well as the values of the regulatory standard.

\subsection{COD Removal}

Fig. 2 shows that the values of the COD of the waste water, treated water and the FEMNV standard are $45 \mathrm{mg} / \mathrm{l}, 20 \mathrm{mg} / \mathrm{l}$ and $40 \mathrm{mg} / \mathrm{l}$ respectively, therefore, the treated water meets the FEMNV COD Standard.

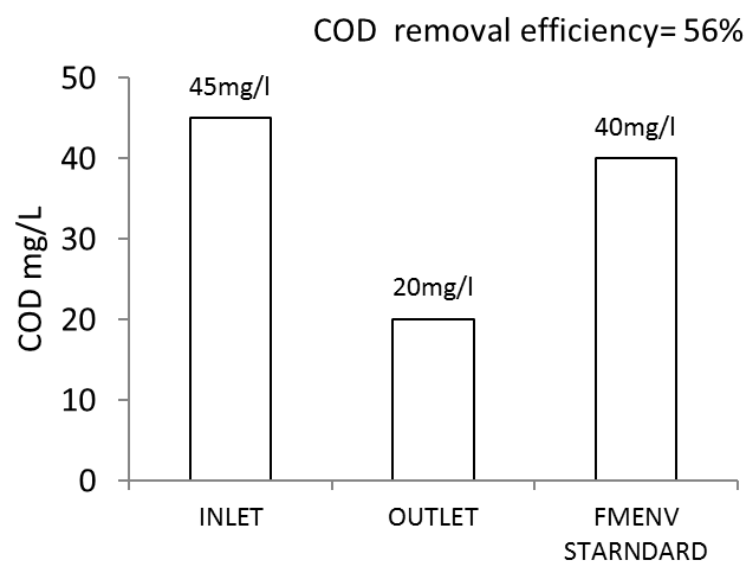

Fig. 2: COD Removal Performance

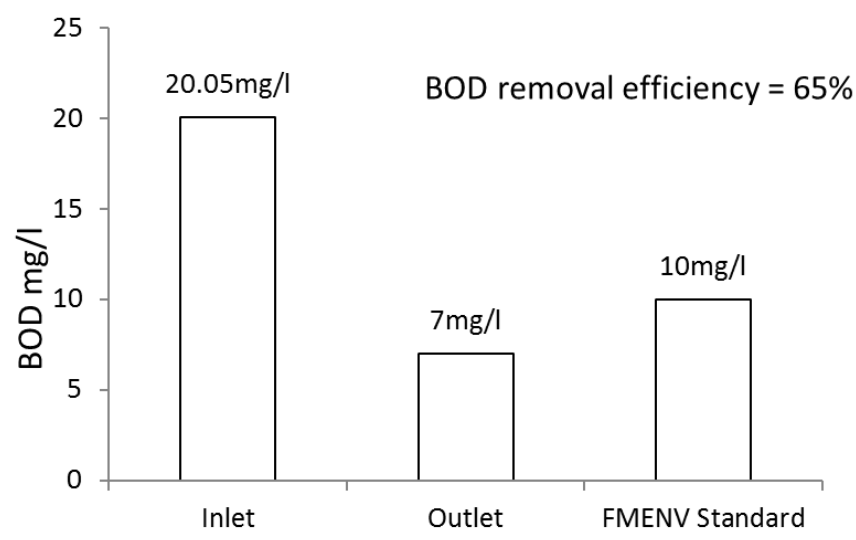

Fig. 3: BOD Removal Performance

\subsection{BOD Removal}

Fig 3 also shows that the values of the BOD of the waste water, treated water and FEMNV Standard. are $20.05 \mathrm{mg} / \mathrm{l}, 7 \mathrm{mg} / \mathrm{l}$ and $10 \mathrm{mg} / \mathrm{l}$ respectively, therefore the treated water meets the FEMNV BOD Standard.

\subsection{TSS Removal}

Fig 4 shows that the values of the TSS of the waste water, treated water and the FEMNV standard are $35 \mathrm{mg} / \mathrm{l}, 10 \mathrm{mg} / \mathrm{l}$ and $30 \mathrm{mg} / \mathrm{l}$ respectively, therefore the treated water meets the FEMNV TSS Standard.

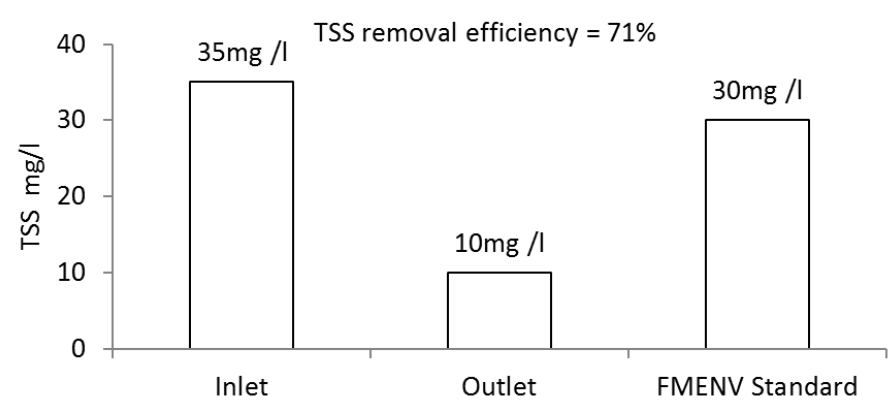

Fig. 4: Total Suspended Solids Removal

\section{4 $\mathrm{NH}_{3}$ Removal}

Fig 5 shows that the values of the $\mathrm{NH}_{3}$ of the waste water, treated water and the FEMNV standard are $27.65 \mathrm{mg} / \mathrm{l}$, $11.55 \mathrm{mg} / \mathrm{l}$ and $20 \mathrm{mg} / \mathrm{l}$ respectively, therefore the treated water meets the FEMNV NH${ }_{3}$ Standard.

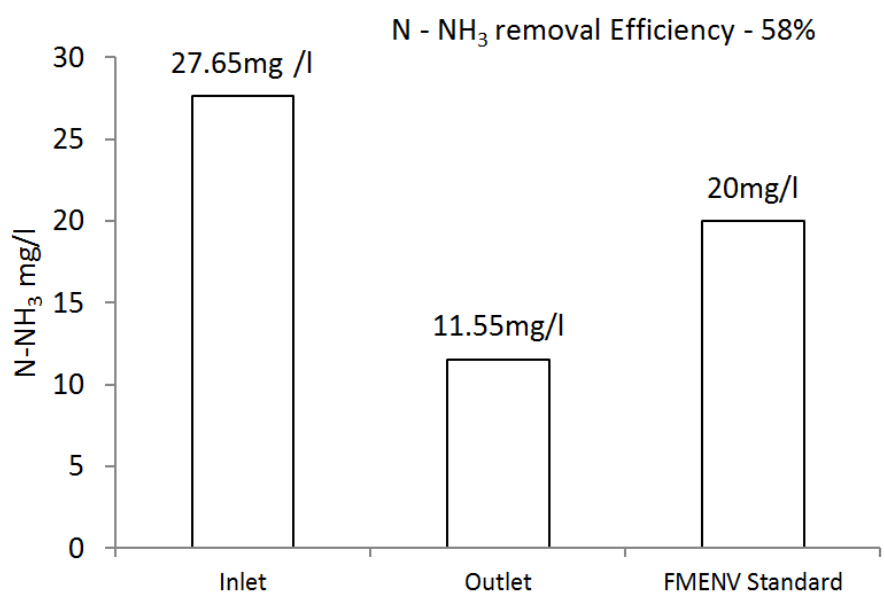

Fig. 5: $\mathrm{NH}_{3}$ Removal Performance

\subsection{Sulphate removal}

Fig 6 shows the values of the Sulphate of the waste water, treated water and the FEMNV standard are $450.08 \mathrm{mg} / \mathrm{l}, 300 \mathrm{mg} / \mathrm{l}$ and $500 \mathrm{mg} / \mathrm{l}$ respectively, therefore the waste water and treated water meet the FEMNV SULPHATE Standard. 


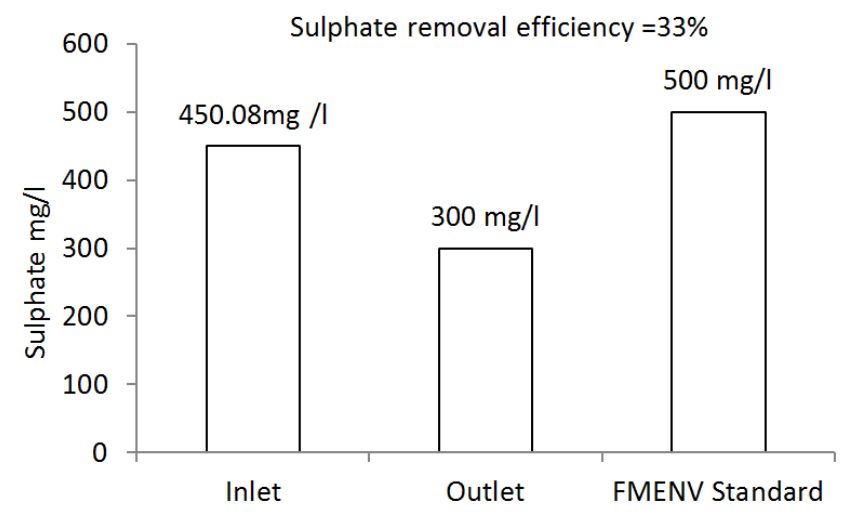

Fig. 6: Sulphate removal performance

\subsection{TDS removal}

Fig 7 shows the values of the TDS of the waste water, treated water and the FEMNV standard are $1800 \mathrm{mg} / \mathrm{l}$, $1000 \mathrm{mg} / \mathrm{l}$ and $2000 \mathrm{mg} / \mathrm{l}$ respectively, therefore the waste water and treated water meets the FEMNV TDS Standard.

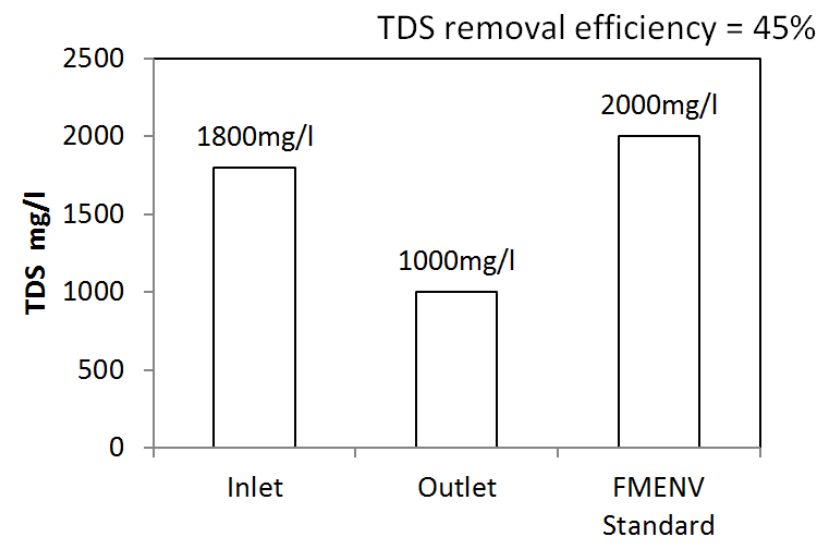

Fig. 7: Total Dissolved solids removal

\subsection{Salinity}

Fig 8 shows the values of the Salinity of the waste water, treated water and the FEMNV standard are $508.06 \mathrm{mg} / \mathrm{l}, 450 \mathrm{mg} / \mathrm{l}$ and $600 \mathrm{mg} / \mathrm{l}$ respectively, therefore the waste water and treated water meets the FEMNV Salinity Standard

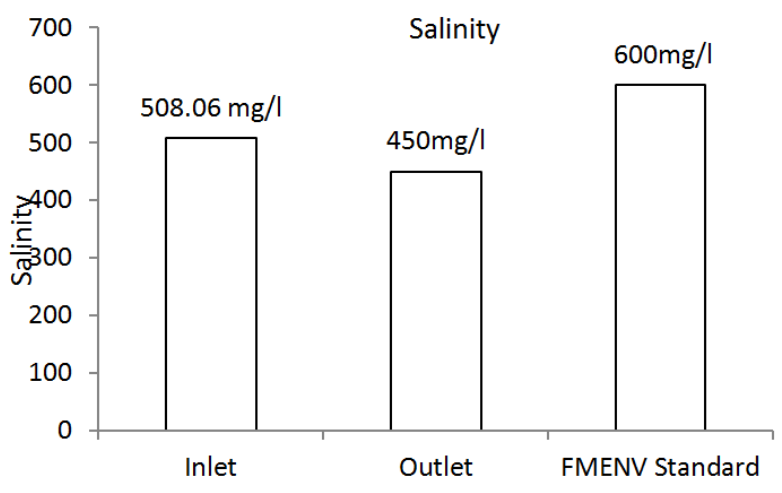

Fig. 8: Salinity Removal performance
The parameters of the treated water at the outlet of the treatment plant in the hotel are within the limits of the Federal Ministry of Environment Standard. The removal eficiency of the various parameters are shown in Table 2 above.

Table 2: shows the removal efficiency

\begin{tabular}{lc}
\hline Parameter & Removal Efficiency (\%) \\
\hline COD & 56 \\
BOD & 65 \\
TSS & 71 \\
NH3 & 58 \\
Sulphate & 33 \\
TDS & 45 \\
Salinity & 11 \\
\hline
\end{tabular}

\section{CONCLUSION}

The COD, BOD and TSS dropped from $45 \mathrm{mg} / \mathrm{l}$, $20.05 \mathrm{mg} / \mathrm{l}$ and $35 \mathrm{mg} / \mathrm{l}$ respectively to $20 \mathrm{mg} / \mathrm{l}, 7 \mathrm{mg} / \mathrm{l}$ and $10 \mathrm{mg} / \mathrm{l}$. While the $\mathrm{NH}_{3}$, Sulphate, TDS and Salinity dropped from $27.65 \mathrm{mg} / \mathrm{l}, 450.08 \mathrm{mg} / \mathrm{l}, 1800 \mathrm{mg} / \mathrm{l}$ and $508.06 \mathrm{mg} / \mathrm{l}$ respectively to $11.55 \mathrm{mg} / \mathrm{l}, 300 \mathrm{mg} / \mathrm{l}$, $1000 \mathrm{mg} / \mathrm{l}$ and $450 \mathrm{mg} / \mathrm{l}$. The domestic wastewater treatment plant of $500 \mathrm{~m}^{3} /$ day capacity had an efficient treatment capability. All parameters, except, lead and chromium met FEMNV standard. The outlet wastewater after the treatment process also met the Federal Ministry of Environment Standard. The results of the case study shows that the activated sludge waste water treatment process could be successfully deployed in sludge treatment in industrial and domestic premises. In hotels where there is near $100 \%$ electrical power availability, the concern for power is not a problem.

The activated sludge wastewater treatment plant could also be economically deployed in areas were the septic tank is unable to drain the waste water into the ground due to impervious layer like clay soil, provided electricity is available.

\section{REFERENCES}

[1] UNICEF Global Water Supply and Sanitation Assessment, 2000 Report, WHO and UNICEF, USA.

[2] Arun, M. Biological Wastewater Treatment. Water Today, August, 2011

[3] Opara, A. U., Nnodim, J. Okorochi E., and Nwanjo, H.O.. Microbial and Physico-Chemical Qualities of Water Source in a Pig-Rearing Rural Community, South 
Eastern Nigeria. International Science Research Journal, Vol. 3, 2011, pp: 125-128.

[4] Sangodoyin, A. Y. and Essien, O.E.. Effect of Urbanisation, Waste Disposal and Hydrological Factors on Flooding of Ogunpa Stream in Nigeria. Discovery and Innovations, Vol. 8, No. 1, 1996, pp 1119.

[5] https://en.wikipedia.org/wiki/Septic_tank

[6] Thomas , E.S. Chemical Engineering Magazine, (2005).

[7] Seedlack, R. I. Phosphorous and Nitrogen removal from Municipal wastewater. 2nd Edition, The Soap and Detergent Association, 1991, Levis Publisher, New York.

[8] Coker, A. O.,Sridhar, M.K.C. and Martins, E.A. Management of septic sludge in Southwest Nigeria. 29th WEDC International Confereence. Abuja, 2003, Nigeria.

[9] APHA Method : American Public Health Association Standard Method for he Examinatioin of Water and Wastewater, 22nd Edition, Washinton DC, USA, 2012.
[10] ASTM American Society for Testing of Materials: Test Methods for Phosphorun in Water, West Conshohocken PA, USA, 1976

\section{NOMENCLATURE}

APHA American Public Health Association

ASTM American Society for Testing of Materials

BOD Biological Oxygen Demand

COD Chemical Oxygen Demand

DO Dissolved Oxygen

FMENV Federal Ministry of Environment

DPR Department of Petroleum Resources

MLSS Mixed Liquor Suspended Solids

NH3 Ammonia

TDS Total Dissolved Solids

TSS Total Suspended Solids

UNICEF United Nations Children's Fund 